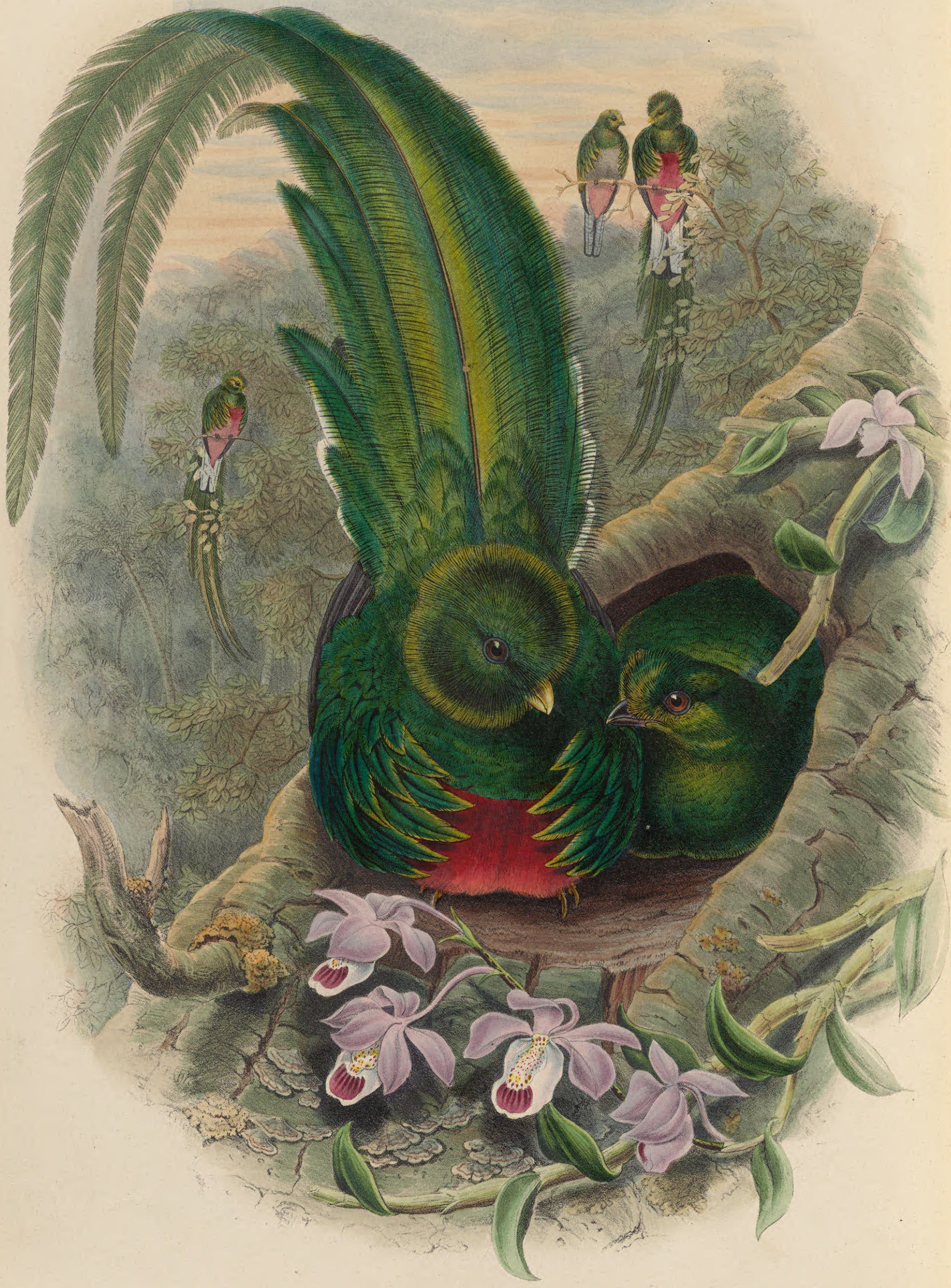

PHAROMACRUS MOCINNO. 


\title{
PHAROMACRUS MOCINNO.
}

\section{Quezal.}

\author{
Specific Character.
}

Trog. cristatus; tectricibus caude superioribus longissimis tripedalibus; suprà et ad guttur pectusque splendidè aureo-viridis; ventre crissoque coccineis; rectricibus sex intermediis nigris, reliquis albis ad basin tantummodo nigris.

Fœem. vel Junior. Capite, gutture pectoreque obscurè viridibus; dorso viridi; ventre cinerascenti-brunneo; crisso coccineo; capite subcristato; tectricibus caude superioribus brevibus; rectricibus externis albis nigro fasciatis.

Rostrum flavum, in junioribus (?) nigrum; tarsi brunnei.

Beak gamboge yellow ; head covered with long filamentous plumes forming a rounded crest; from the shoulders spring a number of lance-shaped feathers, which hang gracefully over the wings ; from the rump are thrown off several pairs of narrow flowing plumes, the longest of which, in fine adults, measure from three feet to three feet four inches; the others gradually diminishing in length towards the rump, where they again assume the form of the feathers of the back ; these plumes, together with the whole of the upper surface, throat, and chest, are of a most resplendent golden green ; the breast, belly, and vent are of a rich crimson scarlet; the middle feathers of the tail black; the six outer ones white for nearly the whole length, their bases being black; feet brown.

Total length, from the bill to the end of the tail, 12 to 14 inches; wing 8 to 9 ; tail 8 to 9 ; tarsi 1 ; length of longest plume about 3 feet.

The female or young of the year have only rudiments of the long plumes, seldom reaching more than an inch beyond the tip of the tail; the feathers of the crest are more rounded and not filamentous ; the feathers of the shoulders but slightly lanceolate; the outer tailfeathers white barred with black, the centre ones black; the whole of the chest, throat, and head obscure green, the remainder of the upper surface bright green; the breast and belly greyish brown; vent fine scarlet; bill black.

Trogon pavoninus. Temm. Pl. Col. 372 (not of Spix).

Pharomacrus mocinno. La Llave, Registr. Trim. i. p. 48 (1831).

Trogon resplendens. Gould, P. Z. S. 1835, p. 29.

paradiseus. Bp. P.Z. S. 1837, p. 101 (1826, ubi ?).

Calumus resplendens. Gould, Mon. Trog. ed. 1.

Pharomacrus paradiseus. Salv. Ibis, 1861, p. 138.

IT is scarcely possible for the imagination to conceive any thing more rich and gorgeous than the golden-green colour which adorns the principal part of the plumage of this splendid bird, or more elegant and graceful than the flowing plumes which sweep pendent from the lower part of the back, forming a long train of metallic brilliancy. Nature appears to have ordained that birds possessing unusual brilliancy of plumage should be inhabitants of retired and obscure situations; and in strict conformity with this law the Quezal, by far the most beautiful of its tribe, is to be found in the most dense and gloomy forests, remote from the haunts of civilized man, which may, perhaps, account for its being so little known to Europeans until within the last few years; for although the long plumes were used to adorn the liead-dresses of the ancient Mexicans, and at a later period were transmitted by the Spaniards from time to time to Europe, yet it is only very recently that we have become acquainted with the entire bird. I believe the first perfect example was received by 
the late Right Hon. George Canning; after that statesman's decease it passed into the hands of Mr. Leadbeater. The representation of this bird in the 'Planches Coloriées' of M. Temminck is undoubtedly the first that was published; but the author evidently confounded it with a nearly allied species discovered in Brazil, and figured in the 'Avium Species Novæ' \&c. of Dr. Spix.

The principal part of the above remarks was published in a former edition of this work nearly thirty years ago. In the long interral which has elapsed much additional information has been obtained respecting this fine bird; and I am greatly indebted to Mr. Osbert Salvin for the full and interesting statement subjoined, which I am sure will be read by every ornithologist with the greatest pleasure :-

"In the 'Ornithology' of Francis Willughby (edited by John Ray, Fellow of the Royal Society, and published in the year 1678), page 385 , will be found 'An Appendix to the History of Birds, containing such Birds as we suspect for fabulous, or such as are too briefly and inaccurately described to give us a full and sufficient knowledge of them, taken out of Franc. Hernandez especially.' Under the heading 'Of fairfeathered Birds' Willughby translates from Hernandez as follows :- 'Its feathers have made the Quetzaltototl more precious than gold; and therefore it is called the bird of feathers. It hath a crest, and is in good part adorned with Peacocks' feathers, of the bigness of a Pie or Pigeon, having a crooked yellow Bill, and Feet something yellow. The Tail is composed of very long feathers of a shining green and of a Peacock colour, like for shape to the leaves of Flouer-de-luce, and covered above with other black ones, but beneath and where they touch the Peacock-coloured or purple ones (which are in the middle) inclining to green, as if nature took care of the beauty of the middle feathers. The crest consists of shining and very beautiful feathers. The breast and neck underneath are covered with a red and shining plumage, and with a purple [pavoninâ], as is also the back and sides under the wings and the belly between the legs; but the feathers in this last place are of a fainter colour, slender, and soft. The feathers of the wings are very long, tinctured with a dilute green and ending in sharp points. The feathers growing on the shoulders are green, but black underneath; but those between the wings are sometimes crooked and of the colour of the claws. The feathers of this bird are highly esteemed among the Indians, and preferred even before gold itself-the longer ones for crests and other ornaments, both of the head and whole body, both for War and Peace, but the rest for setting in feather-works and composing the figures of saints and other things, which they are so skilful in doing as not to fall short of the most artificial pictures drawn in colours. For this purpose they also mingle and weave in together with these the feathers of the Humming Bird. These birds live in the province of Tocolotlan, beyond Quantemallam, towards Honduras, where great care is taken that no man kill them. Only it is lawful to pluck off their feathers, and so let them go naked; yet not for all men indifferently, but only for the lords and proprietors of them; for they descend to the heirs as rich possessions. Francisco Hernandez, in some pretermitted annotations, adds concerning the taking these birds some things worth the knowing. The fowlers (saith he) betake themselves to the mountains, and, there hiding themselves in small cottages, scatter up and down boiled Indian wheat, and prick down in the ground many rods besmeared with birdlime, wherewith the birds entangled become their prey. They fly in flocks among trees, on which they are wont to sit, making no unpleasant noise with their whistling and singing in consort. They have by the instinct of nature such knowledge of their riches that, once sticking to the birdlime, they remain still and quiet, not struggling at all, that they may not mar or injure their feathers. The beauty whereof they are so in love with that they choose rather to be taken and killed than, by endeavouring to get their liberty, do any thing that may deface or prejudice them. They are said to pick holes in trees and therein to build and breed up their young. They feed upon worms and certain wild Pinnce of that sort which Mexicans are wont to call Matzatli. They love the open air, nor hath it been yet found that ever they would be kept tame or brought up in houses. They make a noise not much unlike Parrots, but they have a cheerful and pleasant whistle and they sing thrice a day, to wit, in the morning, at noon, and about sunset.'

"Thus wrote Hernandez now two hundred years ago; and Willughby, his translator, evidently doubted the existence of such a bird as his Quetzaltototl. It was not until the year 1825 that a magnificent bird of the family of the Trogons was made known to science, which ean be no other than the bird Hernandez described so many years before. When seeking for objects for illustration in his well-known work the 'Planches Coloriées des Oiseaux,' M. Temminck had lent to him by Mr. Leadbeater a bird which he described and figured (Pl. 372) under the name Trogon pavoninus, supposing the species to be the same as one then recently described by the Brazilian traveller, Spix, under that name. In 1831, however, De la Llave renamed the same bird, bestowing upon it the barbarous title Mocinno, under which it is now known to the 
scientific ornithologist. Still, neither were Hernandez's notes confirmed, nor was there any thing further recorded respecting the habits of the species, nor yet were the localities frequented by it sufficiently known until the French traveller De Lattre described his visit to its haunts in Vera Paz in the 'Echo du Monde Savant,' in an article which was afterwards reprinted in the 'Revue Zoologique' for 1843. From about this date specimens began to be sent to Europe in some numbers, so that the Quezal was henceforth a wellknown bird.

"In the month of March in the year 1860, during one of my ornithological rambles in Guatemala (the Quantemallan of Hernandez), I found myself at Coban, the chief town of the Department of Vera Paz, and in the very centre of the districts in which Pharomacrus mocinno, or Quezal, is found. From here I made an excursion into the mountains lying to the eastward of Coban for the express purpose of hunting up Trogons in their native haunts, and took with me two of the most experienced Quezal-hunters of Vera Paz. The same afternoon that we reached the forests we intended to explore I was rewarded by securing my first Quezal. We had just started after resting in a deserted rancho of an Indian, and were making our way to the forest across the old corn-patch through which the track passed. I was threading my way amongst the decaying trunks of the felled trees, when Filipe, one of my hunters, came running back to say that Cipriano, the other, had heard a Quezal. Being most anxious to see this bird myself, as well as to be able to boast of its having fallen to my own gun, I hurried up, sat down on my wide-awake in most approved style close to Cipriano, who was calling the bird, and waited, all eyes and ears, for the result. I had not to wait long ; for a distant clattering note warned us that the bird was on the wing, and a moment afterwards there sat on a bough not seventy yards before me a splendid male,-a sight that alone made up for all the toil and disappointments of the previous days. Cipriano wanted to creep up to within shot; but I kept him back, not wishing to lose such an opportunity of watching the actions of this grand bird in its natural state. It sat, as other Trogons do, almost motionless on its perch, the body remaining balanced upon its tiny feet in the same position, the head only being moved occasionally in a slow deliberate way from side to side. The tail was not suspended quite perpendicularly, but hung at an angle of as much as 15 or 20 degrees to the vertical line, and was jerked open and closed again suddenly every now and then, causing the long pendent tail-coverts to vibrate gracefully as they swung in the air. I had not seen all; for a ripe fruit caught the bird's eye, and in a moment he sprang from his perch, all life and activity, plucked the berry and returned to his resting-place. This performance displayed the gorgeous colouring of the bird to the greatest possible advantage. How common a remark it is of people, when looking at stuffed specimens of Hummingbirds, 'What lovely little things these must look in life when they are flying about!' But it is not so, as will be at once seen by placing a Humming-bird twenty yards from you. At that distance how faintly do the brilliant colours show, except in the most favourable light and position. This is not the case with the Quezal, whose brilliant colours reflect themselves in every light. The rich metallic green which forms the chief colour is lustrous, from whatever position it is viewed; and when seen in combination with the deep scarlet of the breast and the pure white of the tail its vividness is, if any thing, enhanced. The brilliant plumage of the living Quezal arrests the eye at once; and thus clothed the bird stands unrivalled, even amongst the feathered denizens of the American tropics. The Birds of Paradise alone hardly surpass it amongst the birds of the east. Such were my passing reflections as I sat with the living Quezal before me, when a low whistle from Cipriano cut my observations short, and the bird, settling on a nearer bough, was a moment afterwards in my hands - the first Quezal I had seen and shot.

"The cries of the Quezal are various. They consist principally of a low double note, whe-0o, whe-00, which the bird repeats, whistling it softly at first and then gradually swelling it into a loud but not unmelodious cry. This is often succeeded by a long note, which begins low, and after swelling dies away as it began. Both these notes can be easily imitated by the human voice. The bird's other cries are harsh and discordant. They are best imitated by doubling a pliant leaf over the first fingers, which must be held about two inches apart: the two edges of the leaf being then placed in the mouth and the breath drawn in, the required sound is produced. Cipriano was an adept at imitating these cries; but I failed to produce them for want of practice. When searching for Quezals the hunter whistles as he walks along, here and there sitting down and repeating the other notes. As soon as he hears a bird answering at a distance, he stops, and imitates the bird's cries until it has approached near enough to enable him to shoot it from where he stands, or to creep up to within shot. The female generally flies up first, and perches on a tree near the hunter, who takes no notice of her, but continues calling till the male (who usually quickly follows the female) appears. Should the male not show himself, the hunter will sometimes shoot the female. The flight of the 
Quezal is rapid and straight; the long tail-feathers, which never seem to be in his way, stream after him. The bird is never found but in forests composed of the highest trees, the lower branches of which (i.e. those at about two thirds of the height of the tree from the ground) seem to be its favourite resort. Its food consists principally of fruit; but occasionally a caterpillar may be found in its stomach.

"Sometimes several males are found together; and then the scene is most exciting as they fly to and fro, their long tails streaming after them.

"Besides the mountains in the neighbourhood of Coban, Quezals are found in several other parts of Guatemala, indeed wherever forests of sufficient extent exist, at elevations varying from 6000 to 8000 or 9000 feet above the sea-level. Such forests are to be seen in the district of San Antonio or Chilasco, above the plain of Salania in Vera Paz, in the high range of Chiantla, the sonthern slopes of the great Cordillera, below Quezaltenango, and in the volcanoes of Agua and Fuego. From all these places I have seen specimens; and in one of the ravines of the last-mentioned, Mr. Godman, who travelled with me in 1861-62, shot a male with the tail-feathers nearly fully grown in the month of December. The months of February, March, and April, however, are the months when the tails reach their full development."

"The only authentic account of the nesting-habits of the Quezal are given by Mr. Robert Owen in "The Ibis' for 1861, p. 66. He there says :- “In an expedition to the mountain of Santa Cruz [Vera Paz], one of our hunters told me that he knew of a Quezal's nest about a league from Chilasco, a place in the same range, and offered to shoot for me the female and bring me the eggs if I would send my servant to help him. This I accordingly did; and my man returned with the hen and two eggs. They stated that they found the nest in a hollow of a decayed forest-tree, about 26 feet from the ground. There was but one orifice, not more than sufficiently large to allow the bird to enter; and the whole interior cavity was barely large enough to admit of the bird turning round. Inside there were no signs of a nest beyond a layer of small particles of decayed wood, upon which the eggs were deposited. The mountaineers all say that the bird avails itself of the deserted hole of a Woodpecker for its nesting-place, probably founding the supposition on the evident inaptness of the bird's beak for boring into trees."

These eggs are of a bluish green colour, without spots or markings, their form is a roundish oval, only slightly more tapering at one end. They measure-axis $1 \cdot 4 \mathrm{inch}$, diameter $1 \cdot 15$ inch.

Considerable variation ean be seen in the dimensions of the long caudal plumes of this bird, even in specimens all coming from the same country; some have the central coverts as broad as the hand and a yard and a quarter long, whilst others are much narrower.

In the southern district of its range (Costa Rica and Veragua) these narrow-feathered birds are alone found; and upon this character chiefly the bird from those countries has been called by Dr. Cabanis Pharomacrus Costaricensis; but the difference seems to be hardly sufficiently pronounced to warrant the separation of the two birds. In Veragua, specimens have been sent me from Chiriqui and the higher Cordillera eastward of that voleano as far as Calovevora, which lies to the northward of the village of Calobre. Beyond this point to the south-east Quezals have not been observed, the low-lying lands of the Isthmus of Panama possessing a hot climate unsuited to their economy.

The figures in the accompanying Plate are taken less than the natural size. 


\section{$2 \mathrm{BHL}$ Biodiversity Heritage Library}

Gould, John. 1875. "Quezal, Pharomacrus mocinno." A monograph of the Trogonidce or trogons 3, -. https://doi.org/10.5962/p.323638.

View This Item Online: https://www.biodiversitylibrary.org/item/264866

DOI: https://doi.org/10.5962/p.323638

Permalink: https://www.biodiversitylibrary.org/partpdf/323638

\section{Holding Institution}

Harvard University, Museum of Comparative Zoology, Ernst Mayr Library

\section{Sponsored by}

Harvard University, Museum of Comparative Zoology, Ernst Mayr Library

\section{Copyright \& Reuse}

Copyright Status: Public domain. The BHL considers that this work is no longer under copyright protection.

This document was created from content at the Biodiversity Heritage Library, the world's largest open access digital library for biodiversity literature and archives. Visit BHL at https://www.biodiversitylibrary.org. 